\title{
THE PROBLEM OF MULTICULTURALISM Radicalism Mainstreaming through Religious Preaching in Surakarta
}

\author{
Zakiyuddin Baidhawy \\ STAIN Salatiga - Indonesia
}

\begin{abstract}
This study aims at identifying the material scope of religious preaching and sermon; and describing the multicultural aspects conveyed in the religious preaching and sermon. As the subject of analysis, it focuses on religious sermons delivered by preachers in Surakarta, Central Java, Indonesia. Using content and discourse analysis, this study finds that: the diversity of the society gains little attention by different religious preachers; instead of multicultural values, the religious preaches and sermons contain some anti-multicultural values, such as selfrighteousness, prejudices and stereotypes of other groups; the subject of religious preaches and sermons implied the intensity of the purification movement; and the development of Islam implies the tendency of religious radicalism as reflected in the hostility towards the local culture, foreign people, and non-Muslims.
\end{abstract}

Keywords: Multiculturalism, Islam, Religious preaching, Radicalism, Salafism.

\section{Introduction}

Surakarta or Solo is often assumed to have a great cultural values (adhilubung) manifested in everyday life of the people, so that people in Surakarta-"Wong Solo" or "Piyayi Sala"-is said as one who has exquisite manner, soft-spoken speech, great aristocratic accomplishment and doesn't like violence. Assumption about the strength of Javanese culture among Surakarta society bears stereotype about diversity pattern of the people in Surakarta, which is assumed to be identical with religious practices, either Islam or non-Islam, in moderate, or even tends to mixed or colored by Javanese culture. 
Up to the end of 1970s, Solonese, including the Muslims, preferred to identify themselves as a Javanese than as the follower of certain religion, especially because Muslims in Surakarta didn't want to be referred to as the fundamentalist by the government. Though intensity of Christianization movement worried Muslims, Surakarta had never had history of religious fanaticism and radicalism both leading to interfaith and intrafaith conflict.

However, since the beginning of 1980s, Surakarta, as in a number of other towns in Indonesia, also showed existence of new enthusiasm of public in Islamic religiosity. Phenomenon of jilbab (headscarf) among Muslim women, for example, started popping out among Muslim students, especially because they were influenced by activists of Masjid Salman ITB (Technology Institute of Bandung). By the end of the 1980s, the visibility of jilbab was no longer limited to students, but also among Muslim women in general. Wearing jilbab as part of Muslim women identity became increasingly fashionable especially since the appearance of ICMI (Association of Indonesian Muslim Intellectuals) which was considered by some of Muslims to be one of "elite" Islamic organization. Besides, in Surakarta there were also some other activities which can indicate enthusiasm on religiosity such as mosque adolescent organizations (remaja masjid), various TPA (Kinder Garden for Quranic Teaching), religious teaching in mosques and majelis taklim (religious teaching circle), religious teaching in offices, and phenomenon of the appearance of what so-called the Jaulah.

At certain degree, religious enthusiasm led to shape militant "exclusive" groups, with their own religious pattern and certain religious behavior. MTA (Majelis Tafsir Al-Qur'an), DDII (Dewan Dakwah Islam Indonesia), LDII (Lembaga Dakwah Islamiyah Indonesia), majelis taklim in Gumuk, majelis taklim in Penumping, beside majelis taklim managed by Muhammadiyah and NU, are among this kind of "exclusive" groups. Exclusive impression was seen because they tended to be suspicious to each other. Lack of communications and cooperation between religious groups in Surakarta are noticeable,

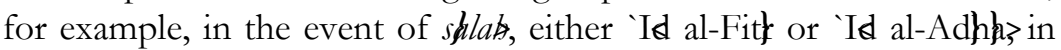
Manahan square, which is a strategic place for big events. When the field was occupied by jama $>b$ MTA from various areas of Surakarta, some of publics around the square did not want to joint praying with them, but making their jama $x h$ ouside and around the field. One of their reasons why they do not want to join with jama $>$ m MTA is that 
they assume that jama $>$ Mh MTA had been manipulated by political mission of the New Order government.

Islamic Radicalism in Surakarta started to emerge and then was widely covered by international media since the collapse of Soeharto's New Order regime. Most Muslims in Surakarta were encouraged to say that they are Muslims and ready to die for Islam. Various Islamic massorganization also formed satgas (paramilitary wing) such as Hizbullah, Jundullah, Barisan Bismillah, KOKAM (Komando Kesiapsiagaan Angkatan Muda Muhammadiyah), and Laskar Jihad (Ahlu al-Sunnah wa al-Jama'ah), which is not just for holding their interests, but explicitly express themselves as an advocate of the united Islam. At certain time, when they feel that their interests are disturbed, some mass organization coalesced, such as in the case of Front Pembela Islam Surakarta (FPIS) or Aliansi Umat Islam Surakarta (AUIS), without paying attention to their own respective interest.

There were rallies and actions done by some mass organizations, such as the protest to Priest Wilson, action demanded the owners of discotheques and night clubs to close their business which then popular with the term "sweeping", action opposed the United States military invasion to Iraq, and action demanding the application of Islamic Shari in legislation system in Indonesia.

Collision almost happened between members of Islamic mass organizations together with Muslim students merged into Front Pemuda Islam Surakarta (FPIS) and a number of non-Muslim community which was supported by paramilitary PDI Perjuangan when Islamic mass organizations protested Pendeta (Priest) Wilson in the interactive dialogue with the theme "Efforts in Overcoming Conflict of Interfaith Community" broadcasted by Radio PTPN Rasitania Surakarta, 3 March 2000. This interactive Dialogue guided by Jeffrey Ohio, one of the broadcasters, presented the guest speaker Priest Ahmad Wilson from Surakarta. Protest to Priest Ahmad Wilson was triggered by the statement in the dialogue that before becoming Muslim, Prophet Muhammad was a Christian. Priest Wilson then was reported to the police by a number of Muslim figures and some members of DPRD (District House of Representatives) from PPP, $\mathrm{PKB}, \mathrm{PK}$, and PAN, so that the radio stopped broadcasting for few days because some of the electronic equipments were confiscated by the police as evidence. But the interesting thing in this case is that among the Priest Wilson's lawyers were personnel from Biro Konsultasi 
dan Bantuan Hukum (BKBH) of Muhammadiyah University of Surakarta. Protest to Pendeta Wilson was merely an event arising from interfaith conflict potency especially since most Muslims in Surakarta worried about the aggressive movement of Christianization in Surakarta in the past two decades.

In Ramadhan 2000, Aliansi Ummat Islam Surakarta (AUIS) which was the alliance from around 25 political parties paramilitary, lasykar and mass organizations such as Zulfikar, Al-Islah, Salamah, Teratai Emas, Honggo Dermo, Jundullah, Hiz̧bullah, Hamas, Hawariyyun, Kopashad, Forkami, FPIS, KOKAM, FKAM, and MTA, gave ultimatum to the discotheque and night club entrepreneurs to close their business during Ramadhan. Besides, they also did sweeping to some nightspots which were unwilling to pay attention to the ultimatum and almost caused the mass conflict between the member of mass organizations and the entrepreneur supporters, mainly consisted of PDIP's paramilitary and people who were considered as abangan (nominal Muslims). Similar collision was also unavoidable between the entrepreneur supporters and the santri (students) of Pondok Pesantren Al-Mukmin Ngruki, who were considered as one of breeding center of Muslim militants.

On Sunday 29 October 2001, at least 150 masses out of four Islamic mass organizations, namely Brigade Hizbullah, Korp Hizbullah Divisi Sunan Bonang, Lasykar Jundullah, and KOKAM did "sweeping" several hotels in Surakarta such as Novotel, Agas, Quality, Sahid Raya, and Lor In, looking for Americans. Such an action was done by Islamic mass organizations as a form of their protest to the US Government for military invasion to Iraq.

The climax action exposing the phenomenon of radical Islamism in Surakarta was increasingly noticeable after the Bali bombing on 12 October 2001. Surakarta was considered to be the breeding ground of radical Islam having network with Jama'ah Islamiyah and international terrorist network, including with KMMM (Kelompok Militer Muslim Malaysia). The perpetrators of Bali bombing and of various other places were assumed to have interrelationship with Ustadz Abubakar Ba'asyir who serves as the leader of Pondok Pesantren Al-Mukmin Ngruki and at the same time as Imam Majelis Mujahidin Indonesia (MMI), known as Islamic group of hardliners. Abu Bakar Ba'asyir, with Abdullah Sungkar, both were the founders of Pondok Pesantren AlMukmin Ngruki and having committed to Darul Islam in 1950s, tried to build Negara Islam Indonesia (Islamic State of Indonesia) by 
developing Jama'ah Islamiyah and built Majelis Mujahidin Indonesia in Yogyakarta in 2000. Abu Bakar Ba'asyir was assumed to have relation to a number of Bali bombers, like Hambali or Ridwan Isamuddin from Cianjur Jawa Barat; Fathurraman al-Gozi from Madiun, former santri Pondok Ngruki; Abu Jibril or Fikiruddin Muqti or Mohammad Iqbal bin Abdurrahman from Lombok; and Agus Dwikarna who was caught in the Philippine for having explosive materials.

The above elaboration indicates that Surakarta represents a plural and multicultural reality. On the one hand, there is moderate Islam, but there is also extremist or radical Islam (hardliners), on the other. Even Surakarta has not had history of social conflict among Muslims, various religious patterns can lead to conflict, especially when the militancy and radicalization ideology is employed for the purpose of political interests. Nevertheless, such a religious diversity is also able to create a space for dialogue and works together among Muslims.

This study aims at analyzing how certain values were developed and contributed to the making of radical Islamism which led to social fragmentation. One of the hypotheses throughout this paper is that religious congregation (jama'ah pengajian) in various mosques and majelis taklim in Surakarta deliver more normative materials, emphasizing individual pietism than social one, and unable to address issues related to living together in pluralism and multiculturalism. The religious materials of this kind in turn could not create space for tolerance to all differences, either in terms of ethnicity, religion or culture.

\section{Discourse about Multiculturalism}

The existence of society with various individuals coming from different background of religion, ethnicity, language, and race are not typical of the West. History has noted that the phenomenon is the reality that happened in the past. Robert W. Hefner for example, affirms that social phenomenon with religious diversity, ethnicity, language, and race in a state or empire have ever happened in Mughal India, Ottoman Empire in the Middle East, West African Empire, and even Majapahit Empire in Java. ${ }^{1}$ So, it can be argued that multiculturalism is no longer unique at this modern century.

It must be admitted that as a discourse, the term multiculturalism has just been introduced in modern times. Historically, the term first of

\footnotetext{
${ }^{1}$ Robert W. Hefner, “Civil Society and Democracy.” Journal, May-June, vol. 2, no. 3 (1998), p. 6, in http://civnet.org/journal/issue7/ftrhefn.htm.
} 
all was introduced in the West -especially in the US and West European countries- in the 1970s. Such discourse arises as the response to the discrimination by a group of majority to that of minority in the 1950s. In those years, the only culture that was recognized in the US and West European countries was the Christian culture of white skin. The other groups in the society were grouped as minority with only limited rights. As a result, various distortions occurred to claim equal right for minority community and a dark skin and color people which started emerging by the end of 1950s. The climax was in the 1960s when the access of the dark and color people was limited in the public sphere by the white. At the same time there emerged struggles of civil rights through various activities and rallies, which assisted them liberate from marginalized position to the equal one in various work areas and business. ${ }^{2}$

The concept of multiculturalism was introduced in America and West European countries by intellectuals, in order to increase human dignity and their humanity. Multiculturalism contains the recognition of difference in equality, either individually or collectively. Here, certain community was seen as a civilized community the pattern of which is like a mosaic. In a mosaic there are many cultures from micro cultures which form larger community (macro culture). ${ }^{3}$

In contemporary discourse, multiculturalism is initially comprehended as term containing race, gender, ethnic, class, and alternative of life style. This definition has just limited to diversity only, and has not touched at other dimension required the diversity of individuals. In this case, Donna M. Gollnick's concept is more adequate. He perceives multiculturalism as "situation where someone has knowledge and develops skill which are needed to enjoy and communicate effectively: (1) to others coming from different cultures, and (2) in so many situation that entangles group of people with different cultural background." 4 Gollnick's concept is said to be more

2 Parsudi Suparlan, "Menuju Masyarakat Indonesia yang Multikultural" (Paper presented at Simposium Internasional ke-3, Jurnal Antropologi Indonesia, Denpasar Bali, 16-21 Juli 2002), pp. 2-3.

${ }^{3}$ Donna M. Gollnick, "Culture and Pluralism," in Donna M. Gollnick and Philip C. Chinn, Multicultural Education in Pluralistic Society (London: The CV Mosby Company, 1983), p. 23.

${ }^{4}$ Gollnick, "Culture and Pluralism," pp. 22-3. 
adequate as it has given possible space to live together between different individuals of ethnic background, culture, and religion.

Dealing with such opportunity for living together, Maman S. Mahayana's concept (2001) in his work Sastra Indonesia dalam Perspektitf Multikulturalisme (Indonesian Art in Multiculturalism Perspective) is clearer. According to him, in social life, the presence of multiculturalism holds two things: (1) that any group of culture can socially be realized, represented, and can live together; and (2) that racism can be reduced through building the positive image of ethnic diversity and through recognition of other cultures. Mahayana's concept does not only guarantee the possibility to coexist in diversity, but also open to mutual-respect in ethnic, language, culture, and religion diversity. Mahayana's concept, nevertheless, doesn't address explicitly the mutual-respect between different individuals and group of peoples. ${ }^{5}$

It is within this context that Nino Ricci proposes more comprehensive concept of multiculturalism. He states that there are three important elements in multiculturalism: diversity, equality, and respect. ${ }^{6}$ In line with Ricci, Lawrence A. Blum maintains that in multiculturalism there are three values namely: realizing one's cultural identity, studying and assessing other cultural heritage; respecting and wishful to comprehend and gets wise to (and from) other cultures besides their own culture; and assessing and enjoying with difference of cultures in itself; that is viewing existence of different culture groups in society as positive kindness to be recognised and maintained. ${ }^{7}$

It has been mentioned previously that multiculturalism is as a matter fact that has existed in some (monarchic) states during the past, including in the Islamic world. In addition to Hefner, there are some scholars who are focusing their study on multiculturalism in Islam. Sachedina maps all important concepts of political Islam which can

\footnotetext{
5 Maman S. Mahayana, "Sastra Indonesia dalam Perspektif Multikulturalisme," Media Indonesia Edisi Akbir Tahun 2001: Satu Indonesia. http://www.mediaindo.co.id/cetak/ berita.asp?ID=2001121011264808.

${ }^{6}$ Nino Ricci, "What is Multiculturalism?," Journal of Canadian Heritage Multiculturalism, vol. March 21, 2002, http://www.pch.gc.ca/multi/what-multi-e.shtml.

${ }^{7}$ Lawrence A. Blum, "Antirasisme, Multikulturalisme, dan Komunitas antar Ras: Tiga Nilai yang Bersifat Mendidik bagi Sebuah Masyarakat Multikultural," in Larry May, Etika Terapan I Sebuah Pendekatan Multikultural, trans. by Sinta Carolina, et al. (Jogjakarta: Tiara Wacana, 2001), p. 19.
} 
improve the relation of humanities, both between nations and among nations. The purpose is to find the normative elements of Muslim tradition and its application to different cultures which is relevant to the pluralistic world of the $21^{\text {st }}$ century. According to him, sociopolitical dimension of doctrine and practice in Islamic history can be mapped into three groups as follows: socio-political dimension in the form of the unity of humankind, socio-political dimension in the form of competition in good works, and socio-political dimension in the form of forgiveness toward humankind. ${ }^{8}$

Meanwhile, Amir Hussain proposes that Islam was firstly presented and grew at pluralistic and polytheistic society. Either in Mecca or in Medina, Islam was initially religious minority among majorities of Christians, Jews, and Zoroastrians. The difference was that in Mecca, Islam occupied position of the oppressed minority and marginalized, while in Medina, though occupied position of minority, Islam can live peacefully with non-Muslim community. As open missionary religion, Islam can grow and has a large number of followers that continuously develops its openness and the Prophet Muhammad always implements interfaith dialogue. ${ }^{9}$

On the other side, Islamic civilization is formed by the cultural diversity, such as Arab, Persian, Turkish, Bengal, Punjab, Sindhi, Maghribi (North African), West African, Middle Asian, and South-East Asian. Islamic civilization involving those cultures gives space and the same attention to Muslim and non-Muslim people, though Muslims plays dominant position. Even, in certain countries, Islamic Shari ${ }_{\mathrm{th}}$ is not the state constitution. Andalusia and India are two important examples of state of which peoples are majority Muslims but are not managed by Shari ah. Lawrence also places al-Biruni as an important figure of multiculturalism that studying Arabic, Persian, Greek, and Sanskrit languages and cultures. He wrote 125 books using Persian and Arabic language.

By combining concepts of multiculturalism proposed by Gollnick, Mahayana, Ricci, and Blum on one side, and multiculturalism theories in Islam described by Sachedina and Hussain on the other side, it can

\footnotetext{
8 Abdulaziz Sachedina, The Islamic Roots of Democratic Pluralism (New York: Oxford University Press, 2000), p. 11.

9 Amir Hussain, "Muslims, Pluralism, and Interfaith Dialog," in Omid Safi (ed.), Progressive Muslims: on Justice, Gender, and Pluralism (Oxford: Bell \& Bain Ltd., 2003), pp. 253-8.
} 
be affirmed that multiculturalism consists of universal values of humanity. The universal values of humanity in multiculturalism covers unity of humankind, competition in good works, forgiveness toward humankind, dialogue or co-existence and pro-existence, living together, equality or egalitarianism, mutual-understanding, mutual-respect, mutual-trust, positive thinking, tolerance, reconciliation, conflict resolution, peace, non-violence, and social justice.

Islam considers that universal values of humanity in the multiculturalism derived from divine revelation, whereas contemporary multiculturalism in Western views such values as coming from logics and philosophy of humanity.

\section{Hegemony of Islam and Javanese Culture}

Religious preaching (pengajian) is basically a socialization process and internalization of values giving contribution in constructing the religious pattern of society. Therefore, identification on tendency of this religious preaching can assist to explain a number of phenomena considered as radicalization of society.

However, Muslims' dynamics in Surakarta is not an independent case. Up to certain level, this dynamics has close relation to the national dynamics of Indonesia, especially to the dialectic between Islam and the State, such as the movements proposing Shari'a as positive law, the mushrooming of Islamic political parties, horizontal conflicts among Muslim and non-Muslim community, the arrest of Abu Bakar Ba'asyir, and the bombings in several places in this country; beside the dynamics of global politics, such as relation between Islam and Western countries, the September 11 tragedy, and the US military invasion to Iraq.

There are ten groups (jama $>$ b) of religious gathering as the focus of this study; those are: Al-Riyadhah, Al-Mufassir, Al-Jami', Al-Ishlah, Al-Muslim, Al-Kabir, Al-Maghrib, Al-Ashalah, Al-Sunnah, and AlQaim. Jama $>b$ of those religious gathering are spread over in various locations in Surakarta, and at certain level they represent various Islamic institutions and religious patterns. Those ten organizations or jama $>h$ are divided into four groups: (1) jama $>h$ with small member (less than 40 members) consisting of adult and elder people; (2) jama $>$ ab with bigger participants (hundreds) and partly the young and; (3) jama $>h$ which is relatively homogeneous and mono-cultural as the result of their Javanese ethnicity and their participation to religious 
gathering of which speakers have the same religious pattern, that is "Islam salafi"; and (4) jama $>$ ah coming from various background in ethnic, level of socio-economy, socio-religious organization, and also political party, so that they are relatively more liquid and multicultural in ideological orientation.

From the above jama $>h$, there are four jama $\mathrm{zh}$ (Al-Ishlah, Al-Jami, Al-Mufassir, Al-Ashalah) whose mission is the same, that is teaching Islam based on the purity of tawhi (the Oneness of God). They formed certain network for the local religious gathering, which is not structural but coordinative, especially through figures that at the same time become the guest speakers in some other gatherings. At least there are four factors bringing them into one. Firstly, the four jama $>$ abs have similar religious pattern as in Al-Ishlah called with "Islam Salafi". Ustaz Mu'allim as one of important figures in the network of jama $>a b$ always avoids labeling which shows categorization. He calls it with term "Dien al-Islam" or "Al-Islam only". According to this figure, Islam having certain character or categorization is not the true Islam.

Second, the four jama abs have political orientation on "Ukhuwwah Islamiyyah" (Islamic brotherhood) that aims at unifying Muslims in terms of politics and power. Ideologically, the four jama $\mathrm{zths}$ have close relation to Al-Muslim under the leader Kyai Ahmad before the independence of Republic of Indonesia that was inspired by movement of pan-Islamism in Saudi Arabia in the early 20th century.

Third, the important figures in those four jama $x h s$ have the same learning tradition, namely tradition of tafsi $\rightarrow$ (Qur'anic interpretation). Most reference delivered by the preachers in the four jama $>b$ are books of tafsi $\gg$ (such as Tafsir $>$ al-Qurtibbi $>$ Tafsi $\gg$ Ibnu Kathi $>$ Tafsi $\gg$ lbnu

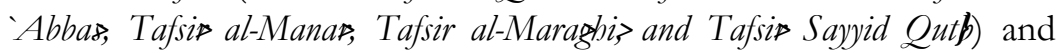

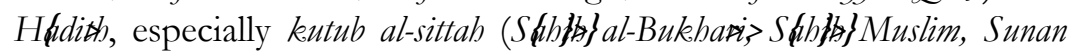
Abi $\gg$ arran Sunan al-Tirmidhi $>$ Sunan al-Nasa $\gg$ and Sunan Ibn Majo), beside Haditas on figh, such as Bulug al-Mararr, Nayl alAwtdr? and Ibarat al-Ahlapar.

Fourth, the four jama zhs have the same mission of purifying the Islamic teachings. The main target of those jama $x h s$ is Muslim who is considered to have been contaminated by elements coming from outside of Islam.

The above explanation shows that the purity of Islamic teaching becomes the major stream constituting the institutional mission of 
most jama $>h$. This emphasis cannot be separated from broader context of dialectic between Islam and Javanese culture. Muslim Community lies in central point of trade-offs between Islam and Javanese culture. Therefore, practices containing symbols of Islamic hegemony and of Javanese culture, such as rites de passage, which is still becoming the essential part of people's life, become the important target of missionary for most of jama $>$ ah gatherings.

The growth of jama $>h$ in Al-Mufassir, Al-Ishlah, Al-Jami', AlAshlah, and Al-Maghrib in certain level, is illustrating the manifestation of "divorce" or at least of the gap between Islam and Javanese culture. Therefore, some traditions in Javanese culture, including some practices carried out by Kasunanan in mosque Al-Kabir, become the main topics in these jama $>$ ah.

One of the factors contributing to the negative perception and even negative attitude of Islam towards Javanese culture is that some of Javanese art is applied as communist propaganda and adopted by Church and Christian institutions as media for missionary, so that various jama $>b$ treats Javanese culture as threatening the Islamic teaching, as communism and Christianity do.

Only jama $>$ Al-Kabir received dialogue between Islam and Javanese culture. Today, Al-Kabir is managed together by The Ministry of Religious affairs, MUI, and Pangageng Parentah (Sultan of) Karaton Kasunanan. In addition, the official members and guest speakers in AlKabir are more dominated by the so-called "traditionalist Muslims." Domination of religious pattern of the official member and guest speakers are based on certain considerations because Kasunanan itself, which historically is the owner of the mosque Al-Kabir, is aware of the existence of other Islamic institutions that are against their tradition, so that Kasunanan until now shows the preference on the traditionalists than other Islamic organizations.

This implies the potential "contestation of power" in jama $>b h \mathrm{Al}-$ Kabir, which sooner or later could "erupt" either openly or silently. AlKabir is strategic place and becomes the central point of hegemony among modernist Islam, traditional Islam, Karaton, and the government. Dominating Al-Kabir can become an important symbol of supremacy over one to another. 


\section{Religious Radicalization}

The popular themes taught in religious gatherings of jama $x h$ basically can be categorized into five: (1) individual piety, (2) social devout, (3) values of internal multiculturalism, (4) values of external multiculturalism, and (5) stigma to others and terrorism.

Themes in various jama $>h b$ emphasize more on individual and social piety, especially among members of Muslims community. Topics on social interaction with others, especially non-Muslim, receives less attention, so that preaching materials dealing with multiculturalism values are relatively little in number compared to the piety, which is related to akblas, figh al-ibalah or tawbis

There are 16 values of multiculturalism in Islam that can be found in various jama $>h$ and in various portion. The values that appear in religious preaching are unity of humankind, competition in good works, forgiveness toward humankind, living together, equality, mutual-understanding, mutual-respect, mutual-trust, positive thinking, tolerance, reconciliation, peace, non-violence, social justice. Multicultural values which do not appear in religious preaching are dialogue or co-existence and pro-existence, and conflict resolution.

The most frequent values of multiculturalism are mutual-respect and mutual-understanding. The numerous multicultural values that can be found in jama ab Al-Riyadhah, among others, are unity of humankind, competition in good work, living together, mutualunderstanding, mutual-respect, mutual-trust, positive thinking, peace, non-violence, and social justice. Equality, mutual understanding, mutual-respect, tolerance, peace, and non-violence can be found in jama $>h b$ Al-Mufassir. Forgiveness toward humankind, mutualunderstanding, mutual-respect, tolerance, reconciliation, peace, and non-violence can be found in jama $>b$ Al-Kabir. Living together, equality, mutual-understanding, mutual-respect, sincerity, positive thinking, and tolerance are in jama $>b$ Al-Maghrib. Unity of humankind, competition in good work, and living together are to be found in jama $\gg h$ Al-Sunnah. Living together, mutual-respect, and tolerance are the characters of jama $\geq h$ Al-Ashalah. In jama $>h$ Al-Jami' there are mutual-understanding and mutual-respect. Inside jama $\mathrm{xh} \mathrm{Al}-$ Muslim there are peace and non-violence values.

Some of values conveyed to various jama $>t h$, especially $\mathrm{Al}-$ Riyadhah, Al-Maghrib, and Al-Sunnah are the multicultural values 
involving non-Muslim community (inter-religious relation); which is taught in jama $>h$ Al-Mufassir and Al-Jami' are the multicultural values of intra-Muslim community; while multicultural values given in jama $>\mathbf{a b}$ Al-Kabir covers the two-internal and external multiculturalismeither Muslim and non-Muslim community, or intra-Muslim community itself.

Beside multicultural values, some religious gatherings also convey anti-multiculturalism sentiment, such as self-righteousness (only Islam or their version of interpretation is correct), prejudices and stereotypes (negative thinking of others, especially the Jews and Christians, and other groups of Muslim, stigma and judgment (labeling that the other is wrong and negative), exclusivism (suggestion not to contact to others), in-group arrogance (that their own group is more superior than the others), defense toward violence (sympathy to violence which has been done by the "right" people), and defense to the disobedience (sympathy to the action of state transgression which has been done by "right" people).

Anti-multicultural values found in jama $\gg h$ Al-Jami' consist of truth claim, prejudice, stigma, judgment, negative thinking, defense toward violence, and defense to the disobedience. Values found in jama $\mathrm{zh}$ AlKabir cover self-righteousness, prejudice, stigma, exclusivism, and defense toward violence. Values found in jama $>b$ Al-Mufassir cover truth claim, prejudice, stigma, and judgment, and in-group arrogance. Values found in jama $>h$ Al-Ishlah cover self-righteousness, prejudice and stereotype, stigma, and negative thinking.

There is no any multicultural value found in Al-Qaim and AlIshlah. Meanwhile, dealing with Muslim-non-Muslim relation, these two jama $>h$ are very different. Al-Qaim doesn't convey multicultural values because it doesn't discuss the relation between Muslim and nonMuslim; while Al-Ishlah discusses the relationship between Muslim and non-Muslim but they are concerned with anti-multicultural values.

Self-righteousness can be found in some big jama $>$ th, they are AlRiyadhah, Al-Mufassir, Al-Jami', Al-Ishlah, Al-Kabir, and Al-Ashalah. Prejudice and stereotype also emerged in part of the big jama'ah except Al-Riyadhah, Al-Muslim, Al-Maghrib, and Al-Qa'im. While stigma and judgment existed in jama $\mathrm{al}$ Al-Mufassir, Al-Jami', Al-Kabir, and AlAshalah; exclusivism appeared in jama $>h$ Al-Ishlah and Al-Kabir; negative thinking can be found as well in jama $>h$ Al-Jami' and AlAshalah; in-group arrogance were in Al-Mufassir and Al-Maghrib; 
defense over violence can be found in Al-Jami' and Al-Kabir; and defense to the disobedience was found in Al-Jami'.

After MUI (Majelis Ulama Indonesia) prohibited secularism, pluralism and liberalism, most of all religious gatherings condemn those who carried such ideologies as 'syphilis'. Liberal Islam Network (JIL) and Jaringan Intelektual Muda Muhammadiyah (JIMM) were slandered everywhere.

Mapping the content of religious gatherings implies the dynamics of social relationship in society, either intra-Muslim communities or between Muslims and non-Muslim communities showing continuity and change. Firstly, in most Muslim community, there is a process of religious radicalization through self-righteousness which gives less appreciation to diversity and practice of living together. This claim emerges especially in the discussion about Islam in relation to other religious teachings and certain values assumed to derive from nonIslam, especially Javanese culture. This claim tends to lead a dialectics between Islam and Javanese culture into disharmony. Positive attitude towards Javanese culture can be found only in jama $>b h$ Al-Kabir. Javanese Culture doesn't become the value reference of society, but it becomes target of criticism and to be blamed for impurity of Islamic teaching. This process could imply the limited forms of cooperation between religious institution of Islam and Javanese culture.

Second, some Muslims experience radicalization process through Islam Salafi which is considered as the ideal and pure Islamic teaching. This radicalization is pioneered by the new jama $>b$ (after the year 1970), such as Al-Jami', Al-Mufassir, and Al-Ashalah. This radicalization implies continued development phase of purification movement since the beginning of $20^{\text {th }}$ century, along with the birth of Muhammadiyah which was then followed by other organizations. The appearance of new organizations is not solely an imitation process, but is reaction to Muhammadiyah that was regarded by them as less assertive in responding a number of certain contemporary issues.

Third, there is tendency to identify Islam as political power which can be mobilized for certain purposes. This political power can't be viewed in terms of political party or power, but as bargaining power or pressure group, as represented by Front Pembela Islam Surakarta (FPIS) demanding the city government to close the entertainment spots during Ramadhan, 'sweeping' the Americans in a number of hotels in Surakarta as a protest to American invasion to Iraq, and 
action of sealing Radio PTPN as a protest to Priest Wilson who was assumed to have offended Islam.

Thereby, for some Muslims in Surakarta, orientation towards Islam Salafi is a need for identity affirmation. Identity affirmation is not merely required in relation to Muslim and non-Muslim, or Islam and Javanese culture, but also in relation to global power which is assumed to be undermining Islam.

\section{The Stricture of Multiculturalism Space}

Religious orientation of jama $>b$ can be distinguished into general and specific orientation. General orientation is the characteristics of all organizations or jama $z h$ : directed to teaching and practicing Islamic doctrine in everyday life, either individually or collectively; most preaching materials are general (without gradation or specification) and; drifted towards undertaking the mission of amr bi al-ma ruf 7 va naby an al-munkar (commanding good and forbidding wrong) to Muslims and not non-Muslims alike; and it doesn't have any certain mission target, such as children, adolescents, the mu'allaf (converts), group of preachers, or other special target audience.

Specific orientation of jama $>b$ can be classified into four categories: (1) to facilitate religious learning, to give opportunity to Muslims to learn Islam by providing source of learning such as kyai, ustadh, and holy book, and place (jama $>h$ Al-Riyadhah, Al-Qaim, AlSunnah, and Al-Muslim); (2) to establish harmony between Islamic teachings and Javanese culture, which is only met in jama $\mathrm{zh}$ Al-Kabir; (3) to purify Islamic teaching from non-Islam elements, either coming from pre-Islam beliefs (Hinduism, Buddhism, animism and dynamism), and also practice of traditions in Javanese culture (jama $\mathrm{xh}$ Al-Mufassir, Al-Jami', Al-Ishlah, and Al-Maghrib); and (4) to strengthen the understanding of Abl al-Sunnah wa al-Jama $>b$ and Javanese culture (Al-Jama'ah Al-Ashalah), by returning to the genuine Islamic teaching. This is due to the idea that Abl al-Sunnab wa alJama $>h$ at certain level has deviated from Islamic teaching as practiced by Rasulullah and his friends (al-Salaf al-S (m) ? One of the factors contributing this deviation is that Javanese culture is assumed to have rooted to religions before Islam (Hinduism, Buddhism, animism and dynamism). This jama $>$ hb also claims that Islam is "Al-Islam", as taught in this jama $>h$. Other forms of Islam, with additional terms (such as 
liberal Islam, secular Islam, progressive Islam, moderate Islam, and others) are not the true Islam.

The above explanation indicates that the dialectics between Islam and Javanese culture continues to exist and can lead to more explicit "conflict". In the early of $21^{\text {st }}$ century, when Muhammadiyah was founded, the dialectics between Islam and Javanese culture began taking place in a subtle "conflict", especially when Muhammadiyah expressed "fights" against takhayyul (heresy), bid'ah (innovation), and kburath (superstition). This step then was followed by some other organizations afterwards, such as Al-Ishlah and Al-Mufassir, and the metamorphosis of Al-Jami' after 1970s led by Usta Mu'allim.

Javanese Culture, historically has extraordinary flexibility in naturalization of other cultural elements, including from Islam, now seems fatigue when confronting to modernist Islam orienting to purification. On the one hand, modernist Islam becomes stronger, especially when supported by various schools and majlis taklim carried out by modernist Muslim organizations. On the other hand, Karaton is not able to maintain harmony of Islam and Javanese culture, whereas institutions of Javanese culture started losing their devotee along with modernization emphasizing at values of rationality and pragmatism.

Pesantren (boarding school) Al-Muslim, which historically has closed relation to Karaton Kasunanan and education institute of Manba' al-'Ulum, causing them to have high appreciation at Javanese culture, underwent such metamorphosis to be an ideological organization, but then it was divided. One of their factions now becomes Al-Muslim education institute.

Though people still use the Javanese language in majlis taklim in villages, including Al-Qaim and Al-Muslim, the preaching material doesn't relate to Javanese culture. It means that the usage of local language in some preaching doesn't have anything to do with harmony between Islam and Javanese culture, but relate to the background of the preachers and members of jama $>$ ab (usually the old).

Meanwhile, orientation of purifying Islamic teaching grows fast and becomes the important issue in various jama $>h$, having great number of members, such as Al-Mufassir, Al-Jami', and Al-Ashalah, or jama $>b$ who become part of national organization, such as Al-Ishlah and Al-Maghrib. Orientation of this purification crystallizes more and becomes more radical, that is Salafi Islam as reflected in Al-Ashalah. 
Popularity of purification oriented jama ah shows uniformity of Islam among Muslims, which in the future enables to reach harmony, so that differences among them, often blocks in unifying the ummah, relatively become fewer. Besides, the agenda to straighten Javanese culture in purification oriented jama $\mathrm{xh} \mathrm{Al}$-Ashalah is a confirmation of their position vis a vis Javanese culture and its institution.

Those phenomena imply that when the difference among Muslims is lesser and the gap between Islamic society and Javanese culture is greater, at that moment multiculturalism space becomes narrower. When there is no certain mechanism which enables dialogue between communities, the narrowness of multiculturalism will enlarge potency of conflict between groups, either between Muslims and non-Muslims, or between modernist and traditionalist Muslims.

\section{Conclusion}

Social diversity, either ethnic, culture, or religion, receives less attention from the preachers in various jama $x h$. Religious preaching emphasizes more on moral, ibachl and aqiah as a response to phenomena of moral decline, such as corruption, robbery, and various immoral acts, so that various jama abs aim to raise morality (piety) by practicing Islamic teaching consequently as priority.

With regard to few multicultural values, there are religious preaching materials which can be categorized as anti-multiculturalism, such as self-righteousness, prejudice and stereotype about other groups of society, in the context of relation with non-Muslim and Western countries, especially the United States and Australia. Non-Muslims are often considered as unbelievers (kuffar $\gg$, musyriki $\gg$ (polytheists), Jews, and Christians.

Materials of religious preaching imply that there is an increase on intensity of purification movement of Islamic teaching. This movement experiences higher level of intensity at the end of $21^{\text {st }}$ century which then crystallized by popularizing "al-Salaf al-Salih". There is also a process of "salafi mainstreaming" through various religious preaching — of four jama $>b$ —and spreading their preachers to any other jama $>b$. In this way, ideology of Salafi develops to the other jama $>$ ah. Along with the increasing of the intensity, religious preaching also implies resistance to Javanese culture, assumed to have big role in "contaminating" the purity of Islam. 
Finally, the development of Islam in Indonesia shows the tendency of radicalization indicated by hostility and hatred speeches to certain groups and ptactices assumed as the threat to Islam. These groups and practices include local culture (considered as source of takhayyul, heresy, and superstition), foreign nation (assumed to be identical to West, especially the US and Australia, which become the source of secularism, pluralism, and liberalism), and non-Muslim communities (assumed to be identical to the Jews and Christians).[]

\section{Bibliography}

\section{Books and Articles}

Blum, Lawrence A. "Antirasisme, Multikulturalisme, dan Komunitas antar Ras: Tiga Nilai yang Bersifat Mendidik bagi Sebuah Masyarakat Multikultural." in Larry May, Etika Terapan I Sebuah Pendekatan Multikultural. trans. by Sinta Carolina, et al. Jogjakarta: Tiara Wacana, 2001.

Elizabeth. What Are Multicultural Issues? http://www.courses.lib.odu.edu/engl/jdavis/mceissues.htm] (accessed on June 2002)

Fananie, Zainuddin and Atiqa Sabardilla. Sumber Konflik Masyarakar Muslim Muhammadiyab-NU Perspektif Keberterimaan Tablil. Surakarta: Muhammadiyah University Press, 2000.

Fananie, Zainuddin et al. Radikalisme Keagamaan dan Perubahan Sosial. Surakarta: Muhamamdiyah University Press and The Asia Foundation, 2002.

Gollnick, Donna M. "Culture and Pluralism." in Donna M. Gollnick and Philip C. Chinn. Multicultural Education in Pluralistic Society. London: The CV Mosby Company, 1983.

Hefner, Robert W. "Civil Society and Democracy." Journal, May-June, vol. 2, no. 3 (1998) in http://civnet.org/journal/issue7/ftrhefn.htm.

Houben, Vincent J.H. Keraton dan Kompeni: Surakarta dan Yogyakarta 1830-1870. Translation from Kraton and Kompeni Surakarta and Yogyakarta 1830-1870. Leiden: KITLV Press, 1994. Yogyakarta: Bentang Budaya, 2002. 
Hussain, Amir. "Muslims, Pluralism, and Interfaith Dialog." in Omid Safi (ed.). Progressive Muslims: on Justice, Gender, and Pluralism. Oxford: Bell \& Bain Ltd., 2003.

Kymlicka, Will. Kewargaan Multikultural, translated by Edlina H. Eddin. Jakarta: LP3ES, 2002.

M. Hari Mulyadi dan Soedarmono (eds). Runtubnya Kekuasaan Kraton Alit: Studi Radikalisasi Sosial “Wong Sala” dan Kerusuban Mei 1998. Surakarta: LPTP, 1999.

Mahayana, Maman S. "Sastra Indonesia dalam Perspektif Multikulturalisme." Media Indonesia Edisi Akhir Tahun 2001: Satu Indonesia. http://www.mediaindo.co.id/cetak/ berita.asp?ID=2001121011264808.

Manning, Chris and Peter van Diermen (eds). Indonesia in Transition: Social Aspects of Reformasi and Crisis. Singapore: ISEAS, 2000.

Nurhadiantomo. Konflik-konflik Sosial Pri-Non Pri dan Hukum Keadilan Sosial. Surakarta: Muhammadiyah University Press, 2004.

Remmelink, Willem. The Cibinese $W$ ar and the Collapse of the Javanese State, 1725-1743. Leiden: KITLV, 1994. Translated by Anas Syahrul Alimi. Perang Cina dan Runtubnya Negara Jawa. Yogyakarta: Jendela, 2001.

Ricci, Nino. "What is Multiculturalism?." Journal of Canadian Heritage Multiculturalism, vol. March 21, 2002, http:// www.pch.gc.ca/multi/what-multi-e.shtml.

Sachedina, Abdulaziz. The Islamic Roots of Democratic Pluralism. New York: Oxford University Press, 1990.

Shiraishi, Takashi. An Age in Motion: Popular Radicalism in Java, 19121926. New York: Cornell University Press, 1990. Translated by Farid Hilmar. Zaman Bergerak: Radikalisme Rakyat di Jawa, 19121926. Jakarta: Grafiti, 1997.

Suparlan, Parsudi. "Menuju Masyarakat Indonesia yang Multikultural", paper presented at Simposium Internasional ke-3, Jurnal Antropologi Indonesia, Denpasar Bali, 16-21 Juli 2002. 